\title{
University-School Collaborative Networks: A Strategy to Improve the Professional Skills of Future Teachers
}

\author{
Rosario Mérida Serrano, María de los Ángeles Olivares García, and Elena González Alfaya \\ Faculty of Education, University of Cordoba, Avenida San Alberto Magno s/n, 14004 Cordoba, Spain \\ Correspondence should be addressed to Elena González Alfaya, elenagalfaya@gmail.com
}

Received 31 March 2012; Revised 18 October 2012; Accepted 23 October 2012

Academic Editor: Bernhard Schmidt-Hertha

Copyright (c) 2012 Rosario Mérida Serrano et al. This is an open access article distributed under the Creative Commons Attribution License, which permits unrestricted use, distribution, and reproduction in any medium, provided the original work is properly cited.

\begin{abstract}
This paper presents an experiment in teaching innovation developed at the University of Cordoba's Faculty of Education (Spain), in the second year of the Infant Education Teacher Training course, within the subject of general didactics. The innovative approach taken focused on setting up a collaborative network between infants' schools and the university. Taking Project Work as the central axis, a learning network has been built with the participation of sixteen Infant Education teachers, three hundred twenty children from this stage, seven university teachers, eighty-five trainee teachers, and two Infant Education advisers from a continuing professional development centre for teachers. The theoretical foundations that support this experiment are described along with their different stages, evaluating the benefits of each of them in facilitating the acquisition of professional competences among university students.
\end{abstract}

\section{Justification}

The teaching innovation presented here is based on the development of a collaborative network between three training institutions: (1) infants' schools for children aged between 3 and 6; (2) the Teachers' Centre (hereinafter TC) which is a public organisation dedicated to the continuing professional development (CPD) of infants' school teachers; (3) the University of Cordoba's Faculty of Education (Spain), as the initial training institution of future infants' school teachers.

The authors' involvement in this teaching innovation experiment is rooted in the discovery that trainee teachers do not acquire quality training during their university studies in order to perform optimally in practical contexts. The evidence leading to this conclusion is based on published research and case studies regarding the quality of university teaching in Spain, which reveal weaknesses in the teacher training processes, as follows: (1) the use of teaching sequences focuses primarily on lectures rather than the student learning process and their actual involvement; (2) the design and development of overly theoretical syllabuses unduly focused on memorising decontextualised contents; (3) providing an education that is far removed from the skills and abilities required in the professional world; (4) the application of a summative evaluation, which adds little to the students' learning, and which at times only deals with aspects of grading; (5) working on topics that ignore the interdisciplinary and transversal nature of education, by presenting learning proposals divided into subjects with no criteria of coordination between them whatsoever; (6) carrying out "imitative" (rather than reflective) practices, where there is no connection or shared reflection between theory and practice, or vice versa [1-9].

On the basis of this general framework, and based on the demands of learning context used, namely, the faculty of education, the main concern here is to address weaknesses in the quality of practices occurring in infants' schools, with a view to improving the professional skills of Infant Education students. Although students identify school practice as one of the most productive periods in their training, the research [10]; and previous experience of the authors as teachers and university administrators of the practicum indicate that $85 \%$ of them are tutored by teachers in Early Childhood 
Education to develop a traditional model of education based on worksheets and commercial materials.

Hence, students do not have the opportunity to learn the educational models they study at university from the practicum. They are only theoretically acquainted with active methodologies regarding the interests of infants' school pupils; however, the expository teaching model they encounter in the classroom does not correspond to their theoretical knowledge and expectations, in most cases.

The small number of teachers willing to tutor students in the Teacher Education Programme makes it impossible for faculty administration to establish prerequisites for selection. Therefore, the teachers who tutor university students in the infants' classrooms are not necessarily committed to teaching improvement and quality. It is largely a matter of luck whether or not students have a strong professional role model.

Considering the power of practice in the socialisation and modelling of teaching behaviour, it becomes clear that, in most cases, ideas addressed in the university context cannot be put into practice if they are not reinforced, supported, and experienced alongside the professionals who implement them and help learners to acquire these skills through their reflective actions. This approach is consistent with Dewey's pragmatism, synthesised in the principle of "learning by doing."

Another weakness of the practicum is the disconnection between the learning processes that exist in infants' schools and the training processes taught at university. There is no culture of collaboration between infant school teachers and the staff at the faculty of education. The teaching culture reveals a wide gap between theory and practice, with very few channels of communication between the two. As a result, university students suffer as a result of the "divorce" occurring between the two institutions and, therefore, are subject to an alien, even contradictory logic and discourse, employed by both learning establishments. As a result of these discrepancies and subdued by the power, charm, and immediacy of practice, the students conclude that theory is not very valuable when it comes to making decisions in the classroom. The devaluing of theory as a means for encouraging teachers to reflect on their teaching performance may lead to routine and mechanical situations that contribute little to educational improvement.

University professors cannot intervene in the organisation of the practicum. Therefore, in a bid to improve this situation, an innovative experiment was implemented based on the creation of a collaborative network between infants' schools, the Teachers' Centre, and the university. The aims were to improve the practical knowledge and/or professional skills of Infant Education students by testing the Project Work (hereafter, PW) method in infants' schools. This methodology will be applied to children aged between 3 and 6 by student teachers working alongside active teachers selected for their track record of applying the PW methodology at this stage, as well as for their commitment to innovation and continuous improvement. The Teachers' Centre was given the task of selecting and training the teachers who would provide quality role models for the students.
The faculty staff members were responsible for training the students about PW theory, organising meetings for those involved in the network, and assessing the professional skills of university students.

\section{Conceptual Framework to Support the Innovation Experiment}

2.1. Practical Knowledge. The primary goal pursued here is to improve students' professional knowledge, so that, in the future, they can participate in the design and development of quality educational experiences. Therefore, the first question tackled was how students built their skills to intervene effectively and critically in different educational settings. The literature relating to the characteristics of teachers' practical knowledge is extensive [11-18], asserting that teaching knowledge comprises schemas, rules, habits, procedures, routines, habits, and inertia that are not innate; that is, they are not activated solely in response to a motivational and vocational genetic factor [19]; instead, they are acquired through teaching socialisation [20], in other words, by immersing people in contexts, institutions, and educational settings where they can build their professional identity through interactions with others.

The question arises as to whether teaching proficiency is only acquired in educational settings. Studies conducted on preprofessional socialisation [21-24] argue that teaching know-how is acquired in practical and school socialisation experiences prior to the teachers' initial training, mainly shaped by their previous school experiences as students. Throughout their personal and professional history, trainee teachers internalise a number of skills, beliefs, values, knowledge, and so forth that structure their personality and their relationships with others, particularly children, which are continuously updated and reused in a nonreflective way, albeit with great conviction, directing their actions, and behaviour in the classroom. In addition to this previous stage of school socialisation, they are influenced by practicum experiences in schools where they had the opportunity to be around Early Childhood Education teachers, observing and participating in different teaching-learning contexts. However, the practical knowledge acquired during their practicum does not guarantee the acquisition of a professional competence aimed at innovation and improvement. The reason is that currently there are practical contexts characterised by routine and immobility serving as training scenarios for students to help them consolidate, legitimise, and perpetuate a technical and traditional conception of Early Childhood Education, overreliant on worksheets, and learning to read and write, understood as the cornerstone of education at these ages.

As indicated by several studies conducted with students in the practicum [21, 25-28], teachers' beliefs during their initial training reveal that at the roots of their actions lie implicit schemas of action and interpretation,which are stable and resistant to the passage of time. These appear to be "permeated" with emotion and are perceived as unquestionable truths that in very few cases are related to 
the teaching theories learned during their degree. Therefore, the theoretical education acquired at university will not necessarily be transferred to working contexts, since these schemas survive the "critical scrutiny" of their initial training and endure far beyond the early years of teaching activity [29].

This difficulty in transferring academic knowledge into infants' schools [30] indicates the need for immersion in professional settings that are recognised for their innovation and improvement, a vital source for students and future teachers to acquire the professional skills they need [31].Their future professional behaviour cannot be influenced purely by the study of theoretical concepts [32]; instead, they should be given the opportunity to partner with teachers considered professional role models, to intervene in infants' schools where the organisation of time, space, and materials provides relevant learning opportunities, and to participate in the development of active methodologies based on the interests and exploratory behaviours of infants' school pupils. It is only through relevant practical experience that one can hope to enable new, innovative ways of doing things in infants' classrooms, by enhancing teachers' professional skills.

2.2. School-University Collaborative Networks. Traditionally, in the field of education, there has been a separation between theory and practice, between those working in schools and those in higher education, between those working with children and those conducting research. However, as pointed out by Tardiff [19], this "branching attitude" only creates misunderstandings and immobility in both institutions. Following international touchstone projects such as the "National Schools Network" and the "Innovative Links between Schools and Universities" in Australia, the IQEA in England, and "Learning Consortium" in Canada, steps have been taken here to create a collaborative network between infants' schools and the university, in order to improve the initial preparation of trainee teachers' as well as the continuing professional development of Infant Education teachers, Teaching Centre advisers, and the academic staff involved. A collaborative relationship has been established which, as Judyth Sachs points out, requires joint decision-making, time, careful negotiation, trust, and effective communication [33]. It is important for faculty staff not to set themselves up as "academic experts" trying to teach Infant Education teachers, but rather as fellow stakeholders who have endorsed a colearning agreement in which all parties are both the subjects and objects of training [34], adopting an egalitarian position and acting as partners for a common purpose: to reinforce a professional dialogue.

The starting premise is that teaching knowledge arises from the dialectical comparison between theory and practice. Theory is used for analysing, reflecting, and making decisions about daily classroom situations, and it emerges from experiences, dilemmas, new developments, and issues that arise in any educational setting mediated by children's interactions. The aim is to build a teaching discourse within the current collaborative network, focused on PW methodology and shared by teachers, Teaching Centre advisers, students, and academic staff. The intention is to create a learning experience which will benefit everyone involved: (1) Infant Education teachers, when interacting with university students, who can bring new ideas, energy, and resources; (2) the advisers who interact with the academic staff and have the opportunity to harmonise continuing professional development with the initial training; (3) university students, since they can learn from professional role models who are experienced in the application of PW methodology; (4) academic staff since it brings them closer to the reality of infants' schools and connects them with professionals acknowledged for their educational excellence; (5) children because they can enjoy more personalised attention and better resources in the classrooms. This is a collaborative learning approach, where each member contributes and complements each other's knowledge and experience with regard to PW. Early individual interventions can lead into forms of interaction shaped by the use of a shared discourse that is woven around negotiations, clarifications of meanings, readings, and shared experiences contributed by the different teaching agents.

One of the first obstacles to be overcome involves breaking down the traditional hierarchy of roles, which places academic staff at a higher level, considering them experts by virtue of their mastery of the conceptual and theoretical framework, ahead of Infant Education teachers, seen as the professionals in charge of applying theoretical principles and instructions to Infant Education scenarios. All individuals within the network must be placed on a horizontal plane of symmetry, allowing the theoretical tools and the practical action strategies to work as different angles of the same reality. One of the basic purposes of the network is to build a professional culture shared by all its participants. This will enable them to understand and apply the PW method, through negotiated meanings, analysis patterns, learning milestones, and evaluation criteria. Through this negotiation and collective learning experiment, the aim is to increase the professional skills of all the parties involved, particularly the Infant Education trainee teachers.

\subsection{Project Work as a Research Method in Infants' Schools.} Considering some of the most notable research conducted in this domain, both within Spain [35-39] and internationally [40-44], PW is understood as a teaching method compatible with the contributions of the constructivist psychology of cognition. It aims to change learners' patterns of knowledge, based on their interests and respecting their ability to explore the physical and social world. It arises from children's intrinsic motivation to learn and their curiosity to explore, discover, understand, and transform the world around them. One of the best-documented research strategies is group work, since it facilitates children's participation in the generation and construction of their knowledge, overcoming practices which require them only to act as consumers of information, by filling in some commercial material foreign to them.

Group exploration, as a basic knowledge-building strategy in PW, is based on Lewin's [45] contributions to ecological psychology. Lewin highlights the dependence of 
human behaviour on the social and environmental context where it occurs. Therefore, the way in which children's educational scenarios are organised will make the learning environments more or less stimulating.

PW embraces this principle and it is developed in classroom contexts with a wide variety of materials and resources, where any object that a child can explore, handle, or which arouses their curiosity is educational. It is the responsibility of the people within the education community to contribute materials and resources related to PW, by recognising the classroom as a learning community in which everyone contributes what they know, as they enrich their own knowledge through exposure to others'.

For that reason, the family plays an essential role in PW, as a network of people that extends, strengthens, and enriches the learning process begun in the infants' school. Family involvement occurs throughout all the stages of this teaching method, beginning with supplying materials and resources, followed by visiting the classroom to share their knowledge, their personal and professional experiences, and finally by collaborating with teachers to evaluate the different educational situations implemented. In short, the purpose here is to involve the community, the families, and the children in a multiple-learning process, an educational process which is especially important for the fascination, collaboration, inquiry, exploration, discovery, creativity, and reflection it engenders [46].

Moreover, in the PW method, the physical context is distributed in a flexible manner, alternating free activity spaces, in the form of the activity corner, with more structured activity areas, such as workshops. Generally, the areas are decorated with elements related to the PW theme, with all the children's work and creations, where the entire classroom becomes a "monographic space" for the PW topic. There is a specific exhibition area where all materials contributed by students, teachers, families, or other community members are exhibited, which will serve as synthesis and material evidence for all the work carried out.

Time management is also established according to the children's learning progress in the PW method. The basic principle is to maintain children's interest and motivation in the learning object or the situation created. Work times are alternated flexibly, between normal classroom routines and rest periods. Usually, it is the children's group exploration process itself that will best determine the use of time. The teaching sequence is maintained while the students are actively engaged in exploration.

According to Dewey [47], in order for PW to be truly educational, it must meet certain conditions: (1) to be of great interest to children; (2) to include relevant learning situations that will enable children to develop skills; (3) to be pleasurable, fun, and motivating; (4) to stimulate children's curiosity, by helping to trigger the mechanisms of exploration and discovery, both on a personal level and collectively. To meet these requirements, the choice of the PW theme is crucial.

The teaching milestones or phases of any Project Work are as follows.
(1) Situational triggers or what's going on? School life is a series of social, emotional, and intellectual events. Teachers must be aware and use any situation that interests the student to draw the maximum educational benefit, guiding teaching milestones so that learners may experience their knowledge. In this method, the role of the infants' school teacher is to employ spontaneous situations occurring in the classroom, and in collaboration with children, to design the most stimulating learning environments possible. Learners themselves are the ones who decide which theme to work on. The topics may emerge from an express wish of any class member as well as everyday situations arising in the classroom or outside of it. A question, a discussion among peers, a discovery outside the classroom, a "gift" brought by children into the classroom, a current event, an experience in their lives, they might all constitute trigger situations for the onset of PW.

(2) Preparation of the interviewer's guide-what do we want to learn? Children, organised in a group, will express what they wish to know about the new chosen theme. Their proposals are formulated as questions and are arranged as a list, which will act as a "roadmap" for the exploration.

(3) Collection and analysis of students' initial ideaswhat do we know? Oral and graphic expressions are collected from children's collages and drawings. Then, their initial ideas are analysed-correct, incorrect, and incomplete-and will be subsequently used as a reference and contrasted with their final thoughts, to verify any conceptual, procedural, and attitudinal shifts achieved.

(4) Teaching-learning activities or situations-what will we do? Each question in the interviewer's guide involves topical trajectories in the conversation that may stray from the guide when he or she feels this is appropriate. The children will be asked what they want to do to answer the previously raised questions. The proposed activities will be arranged and sequenced for the entire duration of the project. The activities they propose will be divided into three stages: (a) documentation, whose mission is to collect all information on the subject of PW (family, community, peers, print, virtual, etc.); (b) production. At this stage children have to organise, analyse, understand, and present the information gathered in the previous phase; (c) evaluation. These are activities in which the students have to show what they have learned. The extent of answer development to their initial questions is used as a reference. Possible activities include preconceptual maps, drawings, letters, photo files, and record-keeping.

(5) PW Assessment. The persons involved in the development of PW will evaluate its quality, by analysing its strengths, weaknesses, and any proposals for improvement. The professional skills required by 
university students to learn the PW method have to be acquired in a practical scenario, as it is impossible to learn without knowing the children's interests, questions, and proposals. However, it is not possible to learn the PW method in all infants' schools. Certain spatiotemporal prerequisites must be fulfilled regarding the social organisation of the classroom, as well as knowledge of this method possessed by the infants' school teacher who supervises the training of future teachers. These prerequisites include a teacher preselection process from among those who apply the PW method in infants' schools, so as to enable university students to acquire essential professional abilities.

\section{Description of the Experiment in Innovation}

As mentioned at the start, this teaching innovation has been developed through a project entitled "school-university collaborative networks through Project Work," in the second year of the Infant Education Teacher Training Diploma Course. This course is part of a Pilot Scheme to apply the ECTS (European Credit Transfer System) and, therefore, has launched different initiatives for change including the design and creation of teaching guides, the establishment of professional skills, and the implementation of academicallyled activities. It is in this context that the experiment presented here was developed.

3.1. Participants. This experiment involved the participation of sixteen Infant Education teachers from twelve state-run and grant-maintained schools in the city and province of Cordoba, three hundred twenty children from this stage, seven teachers from the Faculty of Education, eighty-five students from the teacher training course, and two advisers from the teachers' centre "CEP Luisa Revuelta".

3.2. Stages of the Process. The most significant stages covered in this experiment, which ran from March until May of 2010, were as follows.

3.2.1. Visit to the University Classroom by One of the Infant Education Teachers Who Has Extensive Experience of Innovation Working with PW. Development of a Seminar entitled Project Work: Another Way of Experiencing School, and reading of the book by Domínguez [36] which provided the students' first contact with this learning method and gave them sufficient theoretical material to get involved in the practical application of PW.

3.2.2. Meeting between the Infant Education Teachers Selected to Take Part in the Project, Advisers, University Teaching Staff, and Students. The groups into which students from the subject General Didactics had been divided to work with a cooperative methodology were randomly assigned to one of the sixteen Infant Education teachers selected, who had taken part in a continuing professional development course in relation to this area. Each group met with the teacher to which they were assigned in order to exchange information about the context of the school, the type of pupils, the dynamics in the classroom, the training process they were developing, and, as a priority task, they selected the topic on which the PW would be developed. The choice of the topic was made by agreement between teachers and university students. The teachers presented the subjects that had been raised by the children in the classrooms. Among the two or three topics proposed by the children to their teachers, who in turn presented them to the university students, the latter chose those which seemed best suited to their resources, experiences, and interests. This ensured that the children's interests in the choice of the topic were respected, and that the university students also felt comfortable with the theme. The topics were very diverse in the sixteen classrooms, ranging from The Middle Ages, to Dragons, the Sun, Volcanoes, Birds, the River Guadalquivir to the Circus, and so forth.

3.2.3. First Working Session in the Infants' Schools. The university students, divided into groups, went to the schools to develop their corresponding project in the classroom, with children aged from 3 to 6 years old. The first working session focused on gathering the children's initial ideas and provisional hypotheses about the selected PW topic, which were expressed in collages and through drawings. On this day, the families were also sent a letter asking them to provide documentation. In this session, the documentation stage of the PW was covered.

The collected drawings and the transcription of collages provided evidence that was analysed collaboratively by each university group in the general didactics classes. To do this, the university classroom was turned into a kind of PW planning and design workshop, on the basis of reflection and analysis of the materials provided by the children. Furthermore, after each school session, a dialogue was established involving all the university students, and each group presented their experiences and commented on the notes taken in their research journal. During the week, which was the timeframe established between sessions, the university students and infants' teachers remained in contact over the phone and by e-mail, to outline the learning situations designed and to incorporate the documentation and materials provided by families. This planning was agreed with the general didactics teacher and reflected the most relevant activities that would be developed at the next session in the schools.

3.2.4. Second Working Session in the Infants' Schools. The second session focused on carrying out different activities and experiments that would respond to the questions and concerns raised by the children in the first session as well as working on and analysing the materials provided by the parents. It was a very intense session during which the PW production stage was developed. The week in between the second and third sessions was spent in the university classroom, following the procedure described above, planning the third and final sessions in the schools. 
3.2.5. Third Working Session in Infants' Schools. This final session in the infants' classrooms was dedicated to continuing the development of experiments and activities to respond to the initial questions raised as well as assessing the students. Activities such as brainstorming, dossiers of documents, presentation of materials, creation of murals, parties, and costumes, were all used to ascertain the level of knowledge attained by the children and compare the results obtained with families and different agents in the educational community.

3.2.6. The Last Session on the Project Was Held at the Teachers' Centre. Attended by all the infant education teachers taking part, along with two representatives of the university students, the two advisers involved, and three university teachers, a focus group was organised to analyse the strengths and limitations of the project. The possibility was also broached of continuing with the experiment in years to come, with all collectives expressing their agreement with this proposal.

\section{Evaluation of the Experiment in Innovation}

4.1. Research Design. Given the spatial limitation of this work, the research conducted has been restricted, only presenting the results referring to the university students. A quasiexperimental study is presented as all the variables cannot be controlled and the sample is natural or intact. This research approach, proposed by Campbell and Stanley [48], is able to resolve practical problems pertaining to applied spheres, such as the case examined here. It is a descriptive study, which analyses the level to which students enrolled on the Teacher Training course have acquired certain professional skills, recorded at two different times: at the start (before-test) and end (after-test) of the subject. This information is complemented with content analysis of the group journals kept by the university students and by the focus group composed of the teachers as their tutors in the infants' schools.

\subsection{Exploratory Hypotheses}

(i) Has there been an increase in the students' proficiency in professional skills before and after their participation in the experiment?

(ii) In the event that there has been an increase in their professional skills, are they related to the PW method?

(iii) What lessons have been learned by the university students participating in the network, from their point of view and from that of the Infant Education teachers?

(iv) What strengths, weaknesses, and suggestions for improvement have been identified by the students involved in this innovative experiment?
4.3. Instruments. To evaluate the experiment, a Likert-type Scale created "ad hoc" was applied to all second-year students enrolled on the Teacher Training Course, to assess their Acquisition of Professional Skills at the start (before-test) and end (after-test) of the subject of General Didactics (2nd term), a scale which had already been applied in previous studies [10].

As indicated above, the scale was created by the authors and designed, having made all the relevant adaptations, on the basis of Royal Decree 1393/2007, which establishes the structure and organisation of official university teaching and lists the basic skills required for degree courses, and Order ECI/3854/2007 which indicates the specific professional skills established for the Teacher Training Course. It was not possible to use an internationally validated instrument because none was found that fitted the professional competences included in the Decree. Therefore, a specific instrument had to be constructed for this study.

For each of the items, the students had to reflect their perceived level of acquisition for each of the skills indicated, on a scale from 1 (not acquired) to 5 (fully acquired). The scale incorporated three open-ended questions referring to the strengths, weaknesses, and suggestions the students wished to express. Through the responses provided to the proposed questions, the aim was to ascertain the students' perceptions regarding the acquisition of each of the skills outlined.

The questionnaire was validated through the judgement of experts in the field of general didactics and the performance of a pilot test. In the process of refining the questionnaire, particular attention was paid to the following aspects: avoiding ambiguity and not asking about more than one area in the same question.

Internal consistency was analysed using Cronbach's Alpha coefficient (0.89) to confirm the reliability of the scale. Taking into account the score obtained, the evaluated scale offers high levels of internal consistency; hence, its reliability index can be considered acceptable.

The group journal was also analysed, viewed as a collective research tool that compiles evidence, data, and reflections about the development of the experiment [49], enabling the analysis of its strengths and weaknesses and the perceptions of the university students regarding their interactions in the infants' school settings. Each of the sixteen teams into which the students were divided kept a group journal, which included evaluations of the most significant situations experienced in the four sessions over which the experiment in innovation was developed.

Finally, through a focus group, the sixteen participating teachers gave their views about what the university students have learned the most from the experiment. For this purpose, a semistructured interview was used, with questions about the evaluation of the university students' acquisition of professional skills along with a global assessment of the innovation.

4.4. Data Analysis. The statistical study of the data obtained was based on a descriptive analysis using central trend and variable dispersion measures. This will reflect the students' 
evaluations of their acquisition of each skill at the start and end of the subject. The $t$-test was used to compare equal measures hypotheses for related samples. This test revealed the increase in the acquisition of skills and showed whether there were statistically significant differences between the initial and final level of proficiency. Values of $P<0.01$ were considered statistically significant.

The information was processed using the SPSS v.18 statistical package for Windows.

To carry out the qualitative study referring to the openended questions included in the Likert Scale, the content analysis technique was used, deemed to be an interpretative technique used to analyse narrative material by identifying units of analysis that can help to reveal their significance. As indicated by Bardin [50] "the primordial analytical purpose resolved by content analysis techniques is the identification and explanation of cognitive representations that bestow meaning on all communicative accounts." For this purpose, three categories were established-strengths, weaknesses, and suggestions - coinciding with the open-ended questions included in the scale, and the same numerical code was assigned as to each scale, in order to identify them whilst at the same time preserving the anonymity of the person completing them. Hence, each response was coded with the initial of the dimension to which it corresponded ( $\mathrm{S}$, strengths; $\mathrm{W}$, weaknesses, and $\mathrm{Sg}$, suggestions) and the number of the scale; so S29 would correspond to a strength expressed by the person who completed scale 29 . Subsequently, the frequencies were added up and calculated in terms of percentages, indicating the most relevant and unanimous trends among the people surveyed.

The same technique was used to analyse the group journals, and the focus group, carrying out a process of emerging categorisation based on the nature of the data, without starting from predefined categories. The codification of quotations was carried out by assigning a number corresponding to the session from which the quotation was taken, followed the number of the group expressing it. Hence, 1G2, for example, means that the quotation was taken from the first session and made by group number 2 . To add up frequency totals, the same processes were used as in the open-ended questions on the scale.

4.5. Results. Through the descriptive analysis of the responses provided to the questionnaires used in the study, it was observed, as shown in Table 1 and Figure 1, that the students perceived themselves to have acquired the following professional skills to a greater extent, both in the pretest and posttest stages: (1) value the need for life-long professional development as a teacher; (2) reflect as a group on the need to promote emotional and values-based education in childhood; (3) be able to reflect on classroom practices in order to improve them and innovate. At the posttest stage, in addition to the previous skills, the students perceived that they had increased their level of proficiency in the following areas: know the function and role of infants' schools in the improvement of contemporary society; know the objectives, contents, and evaluation criteria used in Infant Education.
The skills perceived by students as having a lower level of acquisition, both initially and at the end, were as follows: know the evolution of language in early childhood and design language learning situations in multicultural and multilingual contexts; know the dietary, nutritional and early educational needs of childhood; know the educational implications of ICT (especially TV) in childhood development.

Using the $t$-test for related samples, it was shown that statistically significant differences existed between the acquisition of all skills at the start and end of the course, for any level of significance.

As shown in Table 1, the greatest increases were observed in the following skills: (1) know the function and role of infants' schools in the improvement of contemporary society, (2) know the objectives, contents, and evaluation criteria used in Infant Education, and (3) design learning spaces that accommodate the individuality and diversity of infants' school pupils.

The lowest increases, on the other hand, occurred in the following skills: be able to promote social harmony and the peaceful resolution of conflicts that arise in infant school settings; value the need for life-long professional development as a teacher.

Qualitative analysis of the open-ended questions included on the Likert Scale, as shown in Table 2, indicated that the most significant strengths of this experimentation in innovation were (1) knowing the ways of working in the classroom, particularly valuing the opportunity to apply theory-of Project Work-in practice (S27, S32, S33, S39, S46, S48, S53, S54); (2) consolidating theoretical contents, making explicit reference to educational legislation and the different possibilities of organising schools and classrooms in this stage of education (S41, S55); (3) experiencing the complexity of educational action in Infant Education, particularly valuing the hard work of Infant Education teachers (S2), and considering their teaching work as something positive for the future of society (S11).

The most significant weakness detected by the university students in the development of this experiment in innovation was the lack of time to carry out the Project Work in the infants' schools (W2, W14, W27, W36, W37, W49, W60).

As regards the suggestions for improvement made by the university students, closely linked with the weakness they identified, of particular note is that more time should be made available to carry out projects, either by increasing the number of sessions or organising these sessions differently (Sg25, Sg27, Sg32, Sg33, Sg35, Sg46, Sg49, Sg54, Sg56, Sg62).

16 group journals were analysed, each of which included four records corresponding to the four work sessions included in the experiment, giving a total of 64 records. The processes by which they were categorised and codified are summarised in Table 3.

In relation with the design and development of innovative learning situations, the university students' narrations about the sequencing of activities and classroom dynamics revealed a progressive modification in their experiential knowledge, evolving into new schema of teaching activities, based around an alternative methodological framework to the technical and traditional conception of Infant Education. 
TABle 1: Perceived average increases in the acquisition of professional skills, see also Figure 1 .

(A1) Know the objectives, contents, and evaluation criteria used in Infant Education

(A2) Promote and facilitate learning in early childhood, from a global and comprehensive perspective

(A3) Design learning spaces that accommodate the individuality and diversity of infants' school pupils

(A4) Be able to promote social harmony and the peaceful resolution of conflicts that arise in infants' school settings

(A5) Reflect as a group on the need to promote an emotional and values-based education in childhood

(A6) Know the evolution of language in early childhood and design language learning situations in multicultural and multilingual contexts

(A7) Know the educational implications of ICT (especially TV) in childhood development

(A8) (1) Know the dietary, nutritional, and early educational needs of childhood

(2) Know the psychological, learning, and personality-building processes of early childhood

(A9) (1) Know the diversity of actions that comprise the organisation of infants' schools

(2) Value the need for life-long professional development as a teacher

(A10) Be able to give guidance to the families of infants' school pupils

(A11) Be able to reflect on classroom practices in order to improve them and innovate

(A12) Know the function and role of infants' schools in the improvement of contemporary society

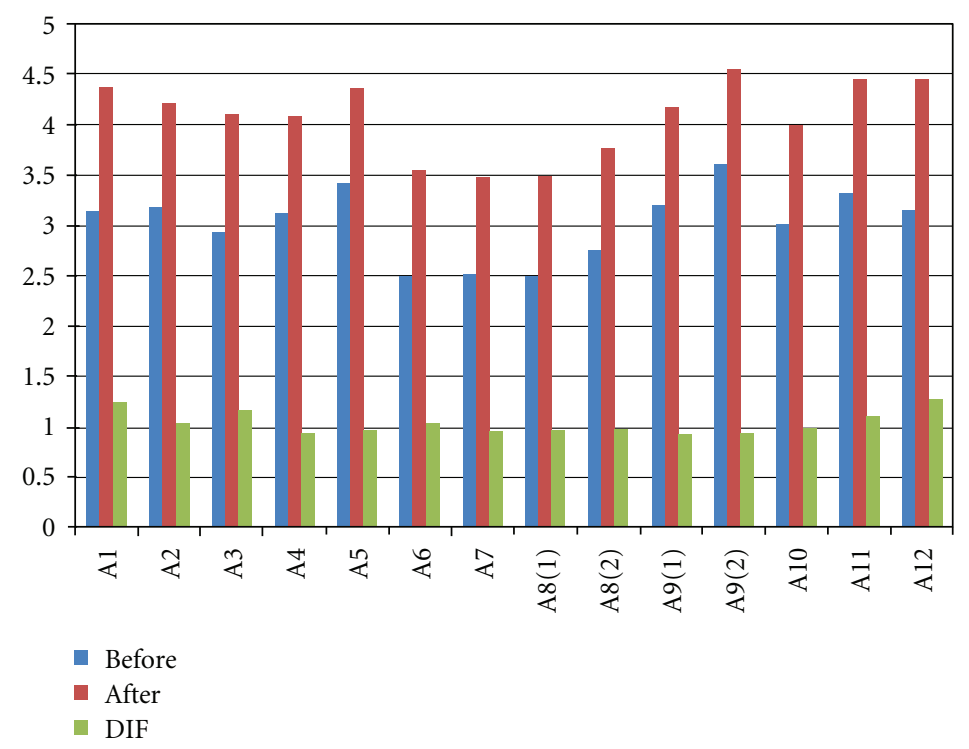

FIGURE 1

TABLE 2: Categorisation of the open-ended questions on the scale.

(1) Strengths

(1.1) Knowing innovative classroom practices

(1.2) Applying the theory of Project Work in practice

(1.3) Experiencing the complexity of educational action in infants' school

(1.4) Consolidating and reinforcing theoretical contents

(2) Weaknesses

(2.1) Lack of time to develop Project Work in the infants' school classrooms

(3) Suggestions

(3.1) Extending or reorganising the sessions at the schools

$66.7 \%$ 
TABLE 3: Categorisation of group journals.

Dimensions

$\%$ frequency

(1) Design and development of active and innovative learning situations

$40.5 \%$

(2) Learning from the infant education teachers, considered professional role models

$28.6 \%$

(3) Complexity of the educational task in Infant Education

$21.4 \%$

(4) Verification of complex capacities in infants' school pupils

$9.5 \%$

From a constructivist approach, learning situations are described that are in line with the foundation principles of the Project Work model. It is worth highlighting, in this regard, the flexible nature of the proposals, attempting to tackle contents pertaining to this stage in a natural and integrated way. Similarly, the group journals identify interactive and interrogative working dynamics based on research and reflection shared by the children with the teachers.

\begin{abstract}
“(...) we presented an activity that they should bear in mind over the week so that they could continue with this topic, which involved seeing if the material (different objects) that we had provided would float in a barrel of water" (2G13).

"Through an experiment, we obtained the colour of the sun. This colour was reflected in paper bags that we took with us, simulating the shape of the sun" (3G12).
\end{abstract}

Carrying out this project allowed the university students to experience new ways of working, whilst at the same time noting an increased motivation in the children's learning.

"After break, we surprised the children with our mediaeval costumes and the ones we had prepared for them using bin bags. The children had a great time, playing freely and exchanging products (bartering) in the market" (4G3).

One of the most highly rated aspects among the students was the work they shared with the infants' school teachers, who they see as quality professional role models. This collaboration influences the professional socialisation of the trainee teachers, by offering them the opportunity to learn from teachers who are specialised in the application of PW in infants' schools and who therefore master the design of active learning situations capitalising on children's abilities. They have had the opportunity to incorporate into their "practical knowledge" alternative methods to the overreliance on worksheets and commercial materials. In this respect, the students highlighted the role played by the teachers as guides and key informants in the design and development of the experiment.

"Initial contact with the infants' school teacher was very positive since it answered a lot of our questions and guided us as regards setting the project in motion. She told us about how she worked with the children in her class group, her experience... and all of this was highly enriching for everyone in our group" (1G14).
The complexity of educational action in Infant Education is patent for all future teachers, who see how they have to reformulate their proposals in accordance with different factors: the interests of the children, suggestions made by teachers and education advisers, parallel activities taking place in the school, unforeseeable events, organisation of spaces and resources, and so forth.

“(...) when the assembly began, we realised that the children had not gotten involved in the search for information, but had simply brought in printed-out information that their parents had looked for on the Internet. So we had to change the assembly meeting, and this set the whole day off kilter. We had to improvise because the children were really over-excited" (3G1).

The planning of activities developed by each group of university students in the schools proved to be a powerful tool to design diverse teaching and learning situations. Hence, planning was used to reflect collectively on their practical experiences, allowing them to analyse their successes and mistakes at previous sessions and firm up proposals for their next actions in the schools. In particular, it enabled them to review basic issues such as the distribution of time and the quality of the activities proposed.

\section{"(...) we are seeing that the activities are too directed and have nothing to do with project work" (3G1).}

Finally, one of the skills developed by the trainee teachers is linked with more finely tuned knowledge of children's learning processes at this stage of childhood. Along these lines, previous beliefs about the capacities and potential of the children were reformulated. The university students possessed a poor and "infantilised" conception of the capacities of children at these ages, resulting from their previous ideas acquired in social contexts and academic settings where Piagetian psychological theories prevail that particularly emphasise what preschool children "cannot" do, instead of focusing on the immense capacities for learning displayed at this stage. This finding is an important advance in the development of their professional skills, since they see the importance of believing in the children's potential to approach innovative proposals for learning and teaching.

"We were really impressed at all the information they had about the topic, the questions they proposed for the following day and the activities they proposed; as well as their explanations and the way in which they expressed themselves" (2G14). 
In the same vein, the participating teachers conveyed their conclusion that the learning experience carried out has allowed university students to discover children's capacities which corresponded more to reality rather than their own prejudices.

\section{"The students learned to shut up and let the children talk instead" (M12).}

Another aspect reported by professionals with respect to the learning acquired by university students was the improvement of basic professional skills such as creativity, autonomy, self-confidence, and the ability to work in teams.

"The teamwork has given them security and cohesion (...) resilience, adaptability and creativity to the reality they were presented with" (M3).

\section{Conclusions and Discussion}

The most significant findings of the study carried out were as follows.

There has been a generalised increase in all the professional skills established for this course following the students' participation in the innovation project outlined here.

The university students feel that the professional skills they have mastered to the greatest extent, both at the start and end of the experiment, are related with continuing professional development, emotional education, and the need to reflect on practices. Having participated in this experiment in innovation, their level of proficiency increased in the skills related with the function of infants' schools in the improvement of society and knowledge of the syllabus at this stage. These acquisitions are consistent with the skills selected in the subject of general didactics. Joining an infants' school not only gave them more in-depth knowledge regarding the design of the syllabus at this stage, since they had to plan teaching and learning activities and proposals adapted to the children's capacities and contexts, but it also gave them a more global understanding of the importance of these institutions in the global development of society. Perhaps it is the university students themselves who are starting to revalue the social importance of a traditionally undervalued profession.

Similarly, the professional skills in which a lower level of improvement was noted after participating in the experiment evaluated here correspond to areas that are far removed from the specific contents of the subject general didactics, identified with the learning of languages in multicultural and diverse contexts, as well as ICT proficiency in childhood, contents pertaining to other subjects included in their degree course.

The strengths highlighted by the students in this experiment are related with knowledge of innovative teaching practices that allow them to put into practice and observe in real contexts the theoretical knowledge acquired in the subject of general didactics, and which are related with the syllabus for this stage, and specifically the design and development of the Project Work method. They also point out as a strength their immersion in infant education settings, which gave them the opportunity to experience the complexity of educational action at this stage. This finding is coherent with the data provided by the statistical study; hence, getting involved in a infants' school classroom, being responsible for developing research-based teaching, and learning proposals, using innovative resources, striving to promote the motivation and participation of the pupils and attending to their diverse personal characteristics, is a magnificent way of learning about the complexity, simultaneity, and unpredictability of teaching action during this stage. The attribution of meaning and the awareness of the usefulness of the knowledge proposed are two unavoidable requirements to increase the interest, involvement, and motivation of the students. As pointed out by Pérez et al. (2009) [8], "apprentices are more motivated and learn better when they experience and investigate real problems."

Another of the positive aspects indicated by the students refers to the opportunity to learn through being in contact with quality professional role models. Learning through modelling and socialisation as regards ways of proceeding in the infant education teaching profession are two of the basic pillars of the training received by students on the Teacher Training Course. At times, the dislocation between theory and practice is so intense that they find it difficult to transfer the learning acquired in the university context to infant education settings. Bridges must be built between initial teacher training and practical infant education contexts, so that students perceive and learn that theoretical-practical interaction is essential for their professional development. Unlike the more conventional approach to linking these elements-first theory, then practice-the experiment in innovation conducted here, based on contributions such as those made by Schön [51], proposes permanent interaction between practice and theory, subscribing to the notion that immersion in the complex contexts of reality and the subsequent provocation of reflection and theoretical analysis is more formative for all the agents involved.

Finally, university students pointed to their reconsideration of the children's capacities. By getting involved and having direct contact with children at this stage, the university students had the opportunity to discover the ideas the children already possess in relation to contents traditionally considered too complex and inaccessible for them. They saw the depth and relevance of the questions they raise, the richness of their previous conceptions, their capacity to link concepts, the power of their creativity, and their capacity to collaborate on a shared task. This transformed their conception of childhood, moving towards narratives that consider the child as cobuilder of knowledge, identity, and culture, acquiring an image of pupils at these ages as beings with a great deal of potential; strong, powerful, competent individuals belonging to a complex social network [52].

Time is the greatest weakness perceived by the university students taking part in this experiment, referring to the number of sessions carried out (four sessions, three of which took place in the schools) as well as their frequency (weekly) and duration (normally over a morning, from 9 a.m. to 2 p.m.). This would be one of the aspects to be reconsidered when designing the experiment for the next school year. 


\section{References}

[1] A. Bolívar, Desarrollo Profesional del Docente en un Modelo Evaluativo de Colaboración, Servicio de Publicaciones de la Universidad de Deusto, Bilbao, Spain, 2002.

[2] F. Angulo, J. Barquín, and A. I. P. pérez, Desarrollo Profesional Del Docente: PolíTica, Investigación y Práctica, Akal, Madrid, Spain, 1999.

[3] J. Torres, La Educación en Tiempos de Neoliberalismo, Morata, Madrid, Spain, 2001.

[4] J. Gairín and C. Armengol, Estrategias de Formación Para El Cambio organizacional, CissPraxis, Barcelona, Spain, 2003.

[5] A. I. Pérez and M. Sola, Informe de la Comisión para la Innovación de la Docencia en las Universidades Andaluzas, CIDUA, Andalusia, Spain, 2005.

[6] F. Imbernón, La Formación Permanente del Profesorado: Nuevas Ideas para Formar en la Innovación y el Cambio: 10 Ideas Clave, Gráo, Barcelona, spain, 2007.

[7] J. Gimeno, Educar por competencias, Qué Hay de Nuevo? Morata, Madrid, Spain, 2008.

[8] A. P. Pérez, E. Soto, M. Sola, and M. J. Serván, Aprender en la Universidad. El sentido del cambio en el EHEA. Guía 1, Akal, Madrid, Spain, 2009.

[9] M. Zabalza, Competencias Docentes del Profesorado Universitario: Calidad y Desarrollo Profesional, Narcea, Madrid, Spain, 2009.

[10] R. M. Mérida and E. González, "La adquisición de competencias en magisterio de educación fnfantil: tendiendo puentes entre el contexto académico y los escenarios laborales," Bordón, vol. 2, no. 61, pp. 77-91, 2009.

[11] G. Ferry, El Trayecto de la Formación. Los Enseñantes Entre la Teoría y la Práctica, Paidós, Ensenada Blanca, México, 1990.

[12] M. C. Davini, La formación Docente en Cuestión: Política y Pedagogía, Paidós, Paidós, Buenos Aires, 1995.

[13] G. Diker and F. Terigi, La Formación de Maestros y Profesores: Hoja de Ruta, Cuestiones de Educación, Paidós, Buenos Aires, 1997.

[14] M. F. Pérez, Análisis Axiológico de las Prácticas de la Organización en Instituciones y Programas Educativos: Decodificación de Mensajes Ocultos y Ocultados, Congreso Interuniversitario de Organizaciones de Instituciones Educativas, Madrid, Spain, 1998.

[15] D. A. Schön, El Profesional Reflexivo. Cómo Piensan los Profesionales Cuando Actúan, Paidós/MEC, Barcelona, Spain, 1998.

[16] G. L. Anderson and K. Herr, "The new paradigm wars: is there room for rigorous practitioner knowledge in schools and universities?" Educational Researcher, vol. 28, no. 5, pp. 12-40, 1999.

[17] R. M. Mérida, La Construcción del Saber Docente, Una Cuestión Compleja, Revista de Ciencias de la Educación, Tavira, Portugal, 17 edition, 2000.

[18] S. E. Noffke, "Research relevancy or research for change?" Educational Researcher, vol. 7, no. 73, pp. 429-431, 2008.

[19] M. Tardiff, Los Saberes Del Docente Y Su Desarrollo Profesional, Narcea, Madrid, Spain, 2004.

[20] A. S. Jurow, "Cultivating self in the context of transformative professional development," Journal of Teacher Education, vol. 60, no. 3, pp. 277-290, 2009.

[21] K. Carter and W. Doyle, "Personal narrative and life history in learning to teach," in Handbook of Research on Teacher Education, J. Sikula, T. Buttery, and E. Guyton, Eds., pp. 120 142, MacMillan, New York, NY, USA, 1996.
[22] D. Raymond, R. L. Butt, and R. Yamagishi, "Savoirs préprofessionnels et formation fondamentale. Approche autobiographique," in Le Savoir des Enseignants: Unite et Diversité, C. Gauthier, M. Mellouki, and M. Tardiff, Eds., pp. 137-168, Logiques, Montréal, Canada, 1993.

[23] D. Raymond, En formation à l'Enseignement: Des Savoirs Professionnels qui on Tune Longue Historie, Simposio Savoirs Professionnels et Curriculum de Formation de Professionnels, Toulouse, France, 1998.

[24] D. Raymond, "Preconceptions des étudiants-maitres et rapports aux savoirs pédagogiques et didactiques," in L'Articulation Didactique-Pédagogie, Enjeu de Formation à l' Enseignement? Y. Lanoir, F. Legault, and C. Lessard, Eds., Presses de'l Université Laval, Québec, Canada, 1998.

[25] H. Borko and R. T. Putnam, "Learning to teach," in Handbook of Educational Psychology, D. Berlinier and R. Calfee, Eds., pp. 673-708, MacMillan, New York, NY, USA, 1996.

[26] J. Calderhead, “Teachers: beliefs and knowledge," in InHandbook of Educational Psychology, D. Berlinier and R. Calfee, Eds., pp. 709-725, MacMillan, New York, NY, USA, 1996.

[27] K. Carter and D. Anders, "Program pedagogy," in The Teacher Educator's Handbook-Building a Knowledge Base for the Preparation of Teachers, F. B. Murria, Ed., pp. 557-592, JosseyBass Publishers, San Francisco, Calif, USA, 1996.

[28] K. Carter and W. Doyle, "Preconceptions in learning to teach," Educational Forum, vol. 2, no. 59, pp. 186-195, 1995.

[29] C. A. Peck, C. Gallucci, T. Sloan, and A. Lippincott, "Organizational learning and program renewal in teacher education: a socio-cultural theory of learning, innovation and change," Educational Research Review, vol. 4, no. 1, pp. 16-25, 2009.

[30] S. Billett, "Personal epistemologies, work and learning," Educational Research Review, vol. 4, no. 3, pp. 210-219, 2009.

[31] I. Henze, J. H. Van Driel, and N. Verloop, "Experienced science teachers' learning in the context of educational innovation," Journal of Teacher Education, vol. 60, no. 2, pp. 184-199, 2009.

[32] E. Young, "Challenges to conceptualizing and actualizing culturally relevant pedagogy: how viable is the theory in classroom practice?" Journal of Teacher Education, vol. 61, no. 3, pp. 248-260, 2010.

[33] J. Sachs, "Reclaiming the agenda of teacher professionalism: an Australian experience1," Journal of Education for Teaching, vol. 23, no. 3, 1997.

[34] J. Wagner, "The unavoidable intervention of educational research: a framework for reconsidering researcherpractitioner cooperation," Educational Researcher, vol. 26, no. 7, pp. 13-22, 1997.

[35] F. Hernández, Los Proyectos de Trabajo. Mapas de Navegantes en Mares de Incertidumbre, Cuadernos de Pedagogía, Barcelona, Spain, 310 edition, 2002.

[36] G. Domínguez, Los Proyectos De Trabajo. Una Escuela Diferente, La Muralla, Madrid, Spain, 2003.

[37] R. Mérida, "Hacia la convergencia Europea: los proyectos de trabajo en la docencia universitaria," Electronic Journal of Research in Educational Psychology, vol. 5, no. 3, pp. 825-852, 2007.

[38] F. J. Pozuelos, Trabajo por Proyectos: Descripción, Investigación y Experiencias, Ediciones MCEP, Cooperación Educativa, Morón, Argentine, 2007.

[39] E. Gómez, R. Mérida, and E. González, "Working projects: a community learning experience between the school and the university," in Proceedings of the International Technology, Education and Development Conference (INTED '10), pp. 002557-002563, Valencia, Spain, 2010. 
[40] S. Chard, The Project Approach: Managing Successful Projects, Scholastic, New York, NY, USA, 1998.

[41] L. Katz and S. Chard, Engaging Children's Minds: The Project Approach, Ablex Publishing, Stamford, Conn, USA, 2000.

[42] S. B. Hong and S. McNair, "Documentation of children's project work: a tool for fostering reflection and reconstruction in preservice and inservice teachers. Teaching strategies," Journal of Early Education and Family, vol. 11, no. 1, pp. 35-42, 2003.

[43] A. M. Clark, "Changing classroom practice to include the project approach," Early Childhood Research and Practice, vol. 8, no. 2, 2006.

[44] M. J. Moran, "Collaborative action research and project work: promising practices for developing collaborative inquiry among early childhood preservice teachers," Teaching and Teacher Education, vol. 23, no. 4, pp. 418-431, 2007.

[45] K. Lewin, "Frontiers in group dynamics: concept, method and reality in social science; social equilibria and social change," Human Relations, no. 1, pp. 5-41, 1947.

[46] R. Mérida, E. González, and A. Olivares, "Adquisición de competencias profesionales del alumnado de Magisterio de Educación Infantil a través de una red de colaboración escuela-universidad," Revista de Investigación en Educación, vol. 2, no. 9, pp. 184-199, 2011.

[47] J. Dewey, Democracia y Educación, Morata, Madrid, Spain, 2004.

[48] D. Campbell and J. Stanley, Diseños Experimentales y Cuasi Experimentales en la Investigación Social, Amorrortu, Buenos Aires, Argentina, 1996.

[49] R. Mérida, "El diario de grupo: una herramienta para la cooperación,” La Brújula de Papel. Revista de Iniciación a la Investigación Psicoeducativa, no. 3, pp. 92-99, 2003.

[50] L. Bardin, Análisis de Contenido, Akal, Madrid, Spain, 2002.

[51] D. A. Schön, La Formación de Profesionales Reflexivos, PaidósMEC, Barcelona, Spain, 1992.

[52] G. Dahlberg, P. Moss, and A. Pence, Más allá de la Educación Infantil, Graó, Biblioteca de Infantil, Barcelona, Spain, 2005. 


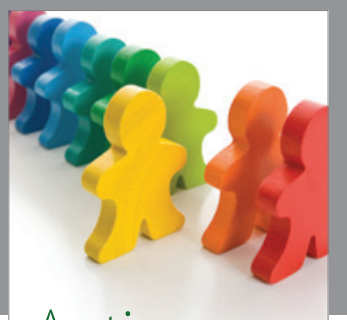

Autism

Research and Treatment
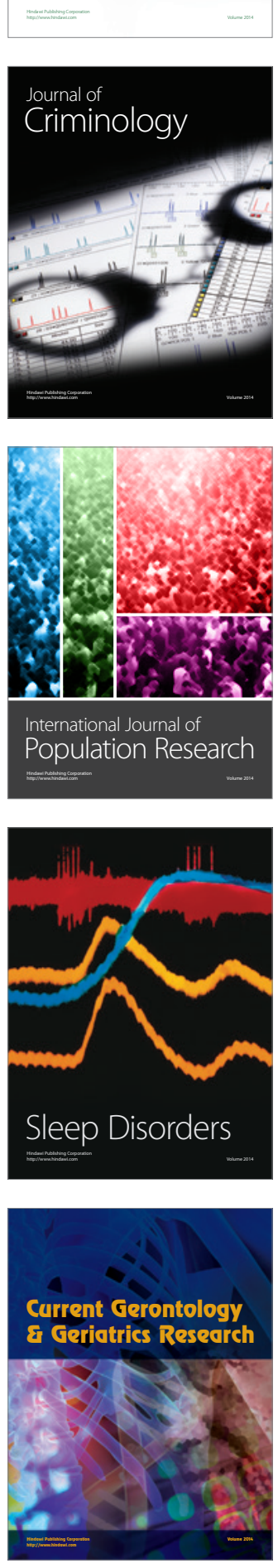
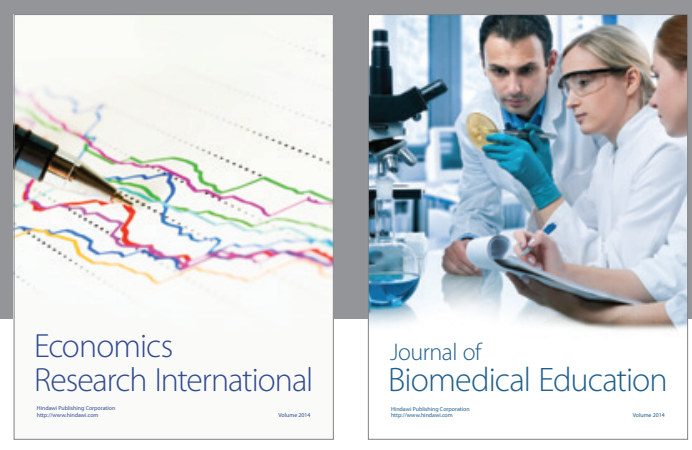

Journal of

Biomedical Education

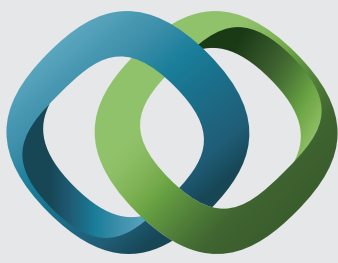

\section{Hindawi}

Submit your manuscripts at

http://www.hindawi.com
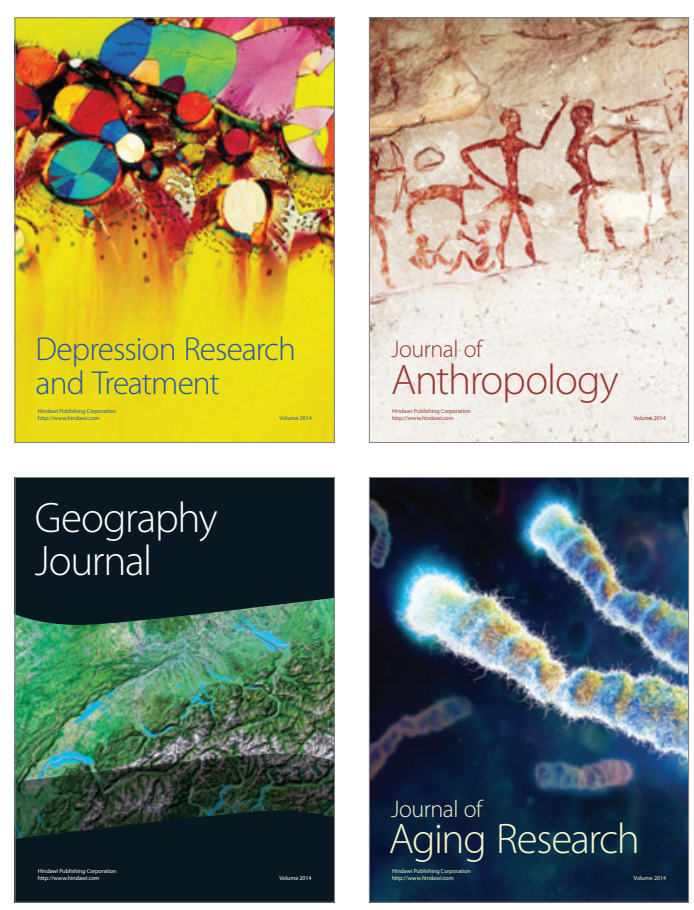

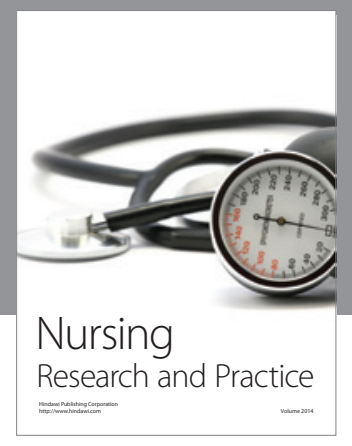

Nursing

Research and Practice

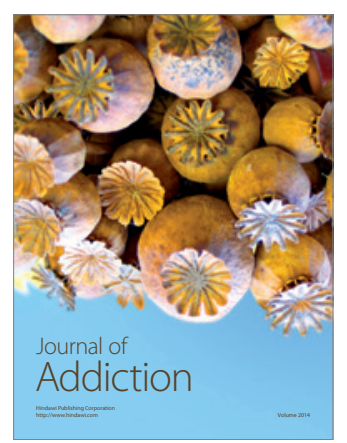

Child Development

Research

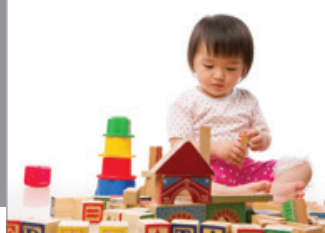

迥
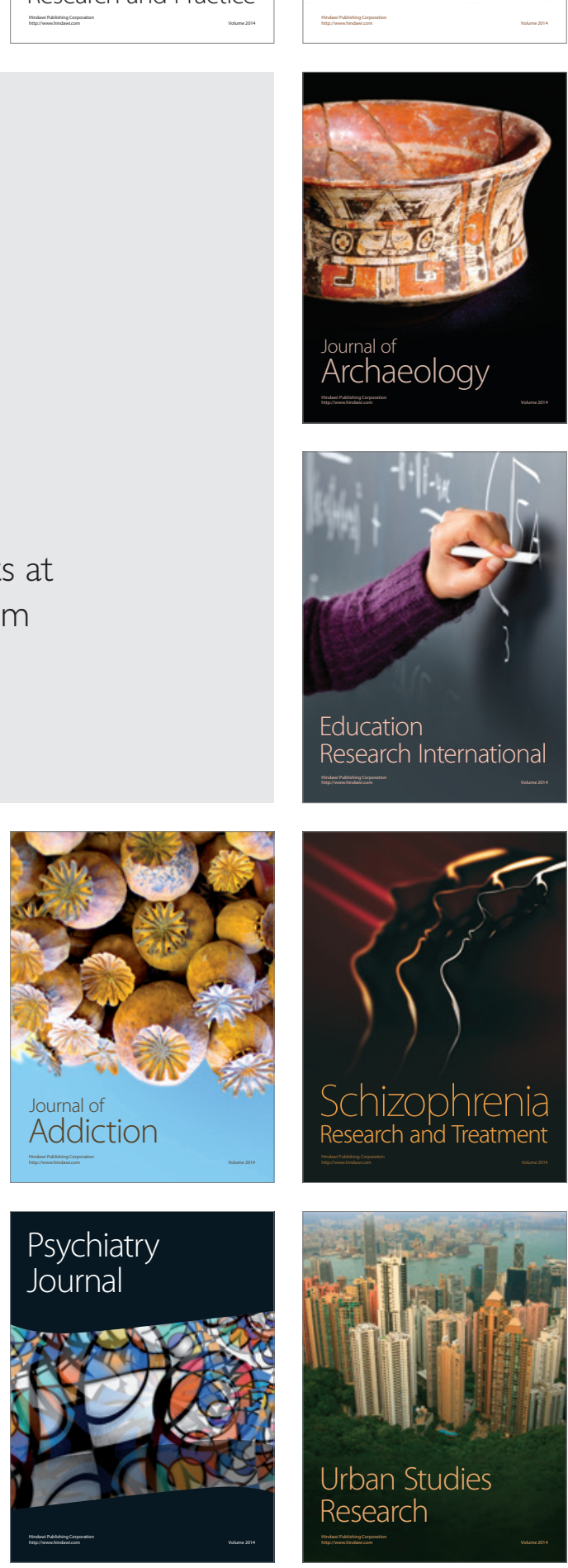